\title{
電子線損傷を与えたイオン結晶表面での高速陽子の散乱*
}

\author{
深澤 優子*1 ·光原 圭*1 ·越智 健太*1 ·松本 雄吾*1 $\cdot$ 塩見 祐樹*1 鈴木 康文*1
}

\section{Scattering of Fast Protons on Electron-irradiated Surfaces of Ionic Crystals}

\author{
Yuuko FUKAZAWA*1, Kei MITSUHARA*1, Kenta OCHI*1, \\ Yuugo MATSUMOTO*1, Yuuki SHIOMI*1 and Yasufumi SUSUKI*1 \\ ${ }^{* 1}$ Division of Science Education, Osaka Kyoiku University, Asahigaoka 4-698-1 Kashiwara, Osaka 582-8582
}

(Received November 8, 2006, Accepted March 3, 2007)

\begin{abstract}
Energy loss spectra and angular distributions of $610 \mathrm{keV}$ protons scattered on the (001) surfaces of the ion crystals are measured. The angle of incidence of protons is smaller than $13 \mathrm{mrad}$. The surfaces have been in-situ irradiated uniformly and the other nonuniformly so that its upstream side for the incident protons is removed preferentially. The surface damages created by the irradiation are observed by an atomic force microscopy (AFM) in air. With increasing the irradiation dose, the energy losses and the peak angles of scattering of the scattered protons are plotted. The results depend largely on the distribution of damages, and are compared with calculated results by a computer simulation. It is found that the change of the angular distributions depends not only on the distribution of damages but also on the angle of incidence of protons to the surface.
\end{abstract}

\section{1. はじめに}

イオン結晶表面に金属を蒸着した場合，一般に 3 次元核 成長をする.下地のイオン結晶表面に予め X 線や電子線を 照射すると, 表面には $\mathrm{F}$ 中心 ( $\mathrm{S}$ 中心) やステップなどの 欠陥が形成され，蒸着物質の成長核 (クラスターやナノ粒子) の形成を促すことが古くから知られている1). セルフサポー トの単結晶薄膜を用いたチャネリング実験に扔いても，X 線照射を行った下地を使って作製した単結晶薄膜が多く用い られてきた ${ }^{2,3)}$. 一方, $\mathrm{X}$ 線や電子線照射により生じるイオ ン結晶表面からの原子の脱着は, layer-by-layerで起こると いうことが知られている4,5).これらの論文によれば, layerby-layer で脱着が起こる低照射量では, 単一原子層高さのス テップのみが形成されるが，更に照射を続けると，表面が荒 れることがわかる．このときステップは様々な高さをもつこ とになる. ステップエッジ付近は, 蒸着された金属原子にと って成長核を形成しやすいサイトの1つで，ステップの高 さが高いほど, より安定な核成長サイトになる。適切な形状 のステップが生成された表面ではより多くの成長核の形成が 期待される.このサイトは広いテラス上や $\mathrm{S}$ 中心の上にで きるナノクラスターにとって最も安定なサイトとは異な る ${ }^{6,7)}$. 蒸着量を増していくことで, 異なる安定サイトから 成長したクラスターが結合する際に生じる歪が以後の膜形成 に影響を与えるはずである。

本研究では，このような金属クラスターの成長の下地とな る結晶表面でのイオン散乱の研究に向けて, 電子線照射で生 じた結晶表面のステップが斜入射イオン散乱に与える影響を 調べた. 蒸着膜にできるステップとイオン散乱についてはす でに詳細な研究がなされているが8), 今回電子線照射量や方 法を変えてステップの密度分布の異なるイオン結晶表面を用 意して散乱イオンのエネルギーと角度分布を測定し, その結

* 平成18年11月 8 日 第47回真空に関する連合講演会で発表

*1 大阪教育大学 (干582-8582 大阪府柏原市旭ヶ 丘 4-698-1)
果をシミュレーションと比較した. 実験結果とシミュレーシ ヨン結果の対応を付けるため, 試料表面を原子間力顕微鏡 （AFM）で観察し，表面の欠陥の形や密度を調べた。

\section{2. 実 験}

実験は $10^{-8} \mathrm{~Pa}$ 台の超高真空中で行った。実験装置は既に 別の論文で述べているが9), 今回の研究に必要な装置の概要 をFig. 1 に示す。試料は $\mathrm{KCl}$ であり，(001)䢃開面でビー ムが散乱するようにゴニオメータに取り付け, 表面は真空槽 ごとベークアウトすることにより清浄化した. 奈良女子大学 理学部物質分析用加速器にこの散乱槽を接続し, 加速器から の $610 \mathrm{keV} \mathrm{H}^{+}$を通した. イオンビームは 2 つの XY スリッ トで $0.1 \mathrm{~mm}$ 角程度にコリメートし，ゴニオメータ上の試料 に入射した. 入射角 $\left(\theta_{\mathrm{i}}\right)$ は試料の $(001)$ 面に対し数 $\mathrm{mrad}$ の角度である. 入射するイオンビーム量で測定值を規格化す るために，上流のスリットに流れ込む電流をモニターした． イオンの入射条件は，入射角を変えずに入射方位角を変える ことでランダム（鏡面反射）と〈100〉チャネリング（表面チ ヤネリング）の 2 通りを行った. 散乱されたイオンを, 受 け角 $\pm 0.7 \mathrm{mrad}$ の点スリットで選別し, 半導体検出器で検 出することにより, 散乱角度分布 ( $\theta$ 分布) とエネルギー損 失スペクトルを測定した. 実験中に試料の温度は $100^{\circ} \mathrm{Cに}$ 保 った.

試料への電子線の照射は, イオンビームの下流側から試料 に対して $45^{\circ}$ の角度で行った. 超高真空中で逐次, 電子線照 射を行い, 試料表面で散乱したイオンを観察した. 電子線を 試料表面の全面に均一に照射した試料と, 非均一に照射した 2 種類の試料で観察を行った. 均一な照射は電子銃からの電 子ビーム（直径約 $15 \mathrm{~mm}$ ) の直径部分を $0.6 \mathrm{~mm}$ のスリット でコリメートし，そこを通過した縦長の電子ビームを左右に 往復偏向させることにより行った. 非均一に照射した試料で は, 電子ビームをイオンビーム上流側に強く照射し，イオン ビームにとってアップステップが優先的に形成されるように した.いずれの場合も電子ビーム量は電子線を偏向し, 近く 


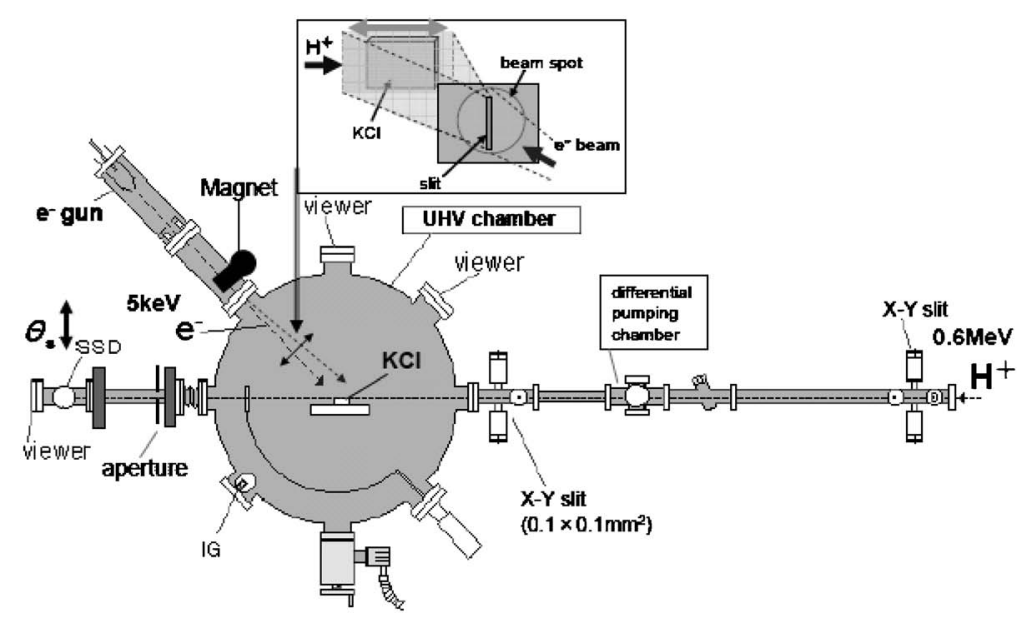

Fig. 1 Schematic diagram of experimental apparatus.
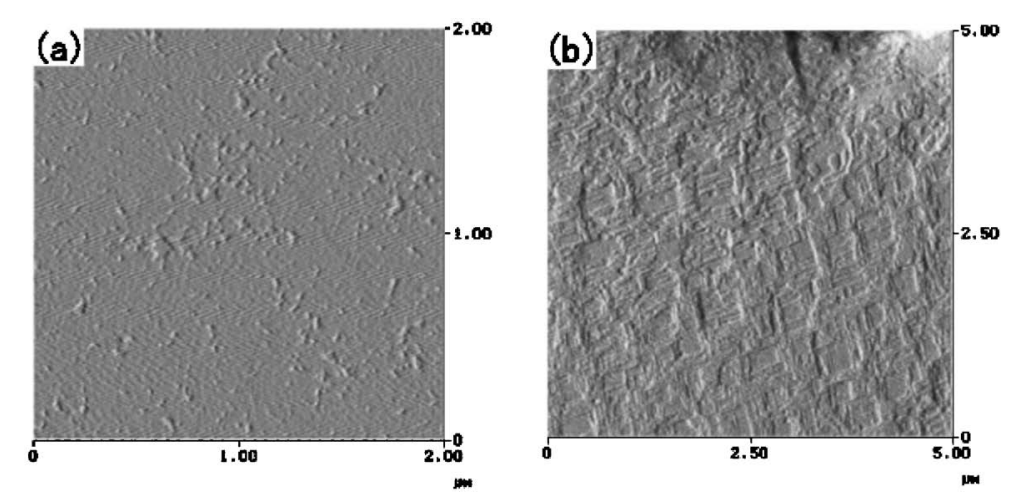

Fig. 2 Error signal mode images of the (100) surfaces of $\mathrm{KCl}$ observed by the AFM. (a) $2.0 \times 10^{16} \mathrm{~cm}^{-2}$. (b) $2.0 \times 10^{17} \mathrm{~cm}^{-2}$.
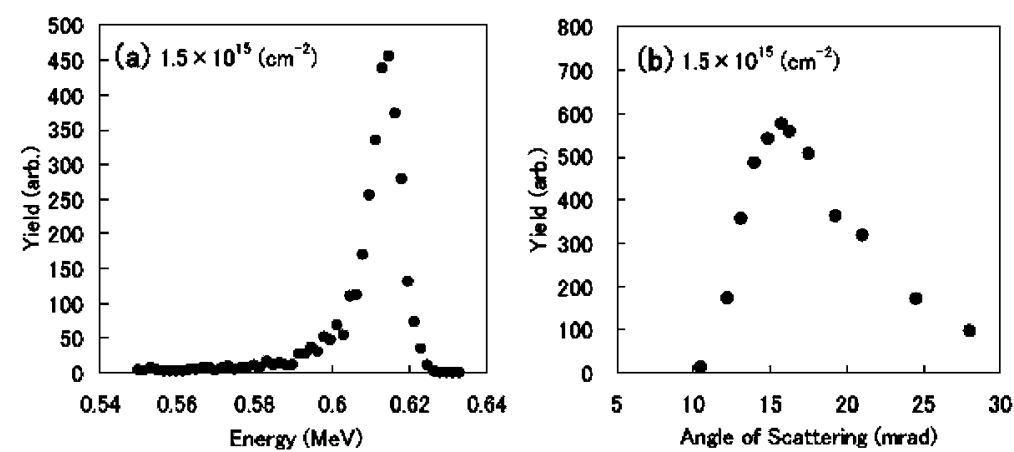

Fig. 3 An example of the energy spectra and angular distributions of protons for the uniformly irradiated sample. (a) Energy spectra. (b) Angular distribution.

に置いたファラデーカップに入射することによって測定した. 最後の照射が終わったあとの試料を取り出し, 神戸大学・ 研究基盤センターのAFM （Bio Scope NVB100; Digital Instruments）によって空気中で観察した。

\section{3. 実 験 結 果}

AFM で観察した試料表面の例を Fig. 2 に示す。 $2.0 \times$ $10^{16} \mathrm{~cm}^{-2}$ の電子線照射をした試料(a)には大きさ数 $\mathrm{nm} \sim 50$ $\mathrm{nm}$, 深さ $2 \mathrm{~nm}$ 程度の矩形の穴が多数見られる. $2.0 \times 10^{17}$ $\mathrm{cm}^{-2}$ の電子線照射をした試料(b)は浸食が進んで矩形に切 り取られている. 矩形内に狭い間隔でステップを見つけられ
ることから層状に剥がれた結果といえる, に電子線を照射した試料は, 照射量の多い上流側が荒れてい ることが分かった. 上流側の表面の層状剥離が進んだ結果, イオンビームにとってアップステップの多い傾斜した表面が 形成されていると考えられる.

均一に電子線照射を行った結晶表面からの散乱 $\mathrm{H}^{+}$のエネ ルギースペクトルの例を Fig. 3(a)に, エネルギースペクト ルのピーク付近の収量をプロットして描いた散乱角分布の例 をFig. 3(b)に示す。いずれもランダムな方位角で入射し， 入射角は (001) 面に対し $7 \mathrm{mrad}$ である. 均一照射した試料 に対し $7 \mathrm{mrad}$ で入射したときの, 散乱角分布のピーク付近 

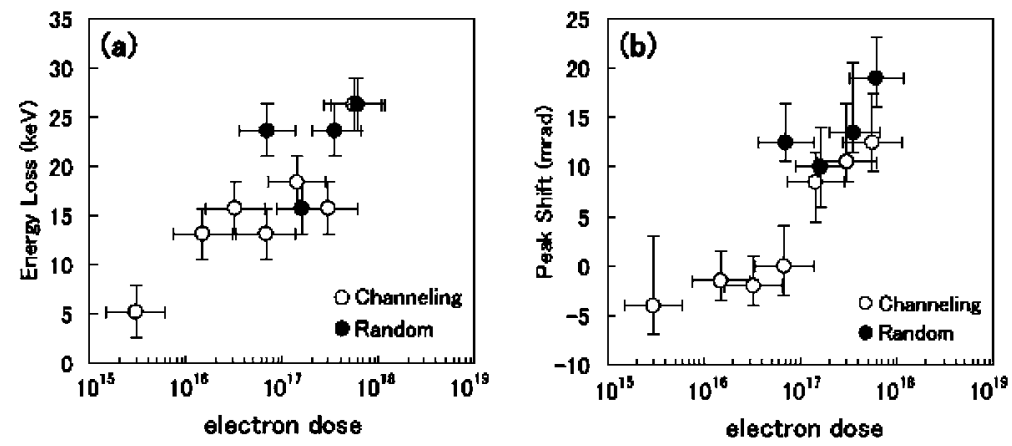

Fig. 4 Energy loss and peak shift of the angular distribution at $13 \mathrm{mrad}$ incidence angle for the nonuniformly irradiated sample. (a) Energy loss. (b) Peak shift of the angular distribution.
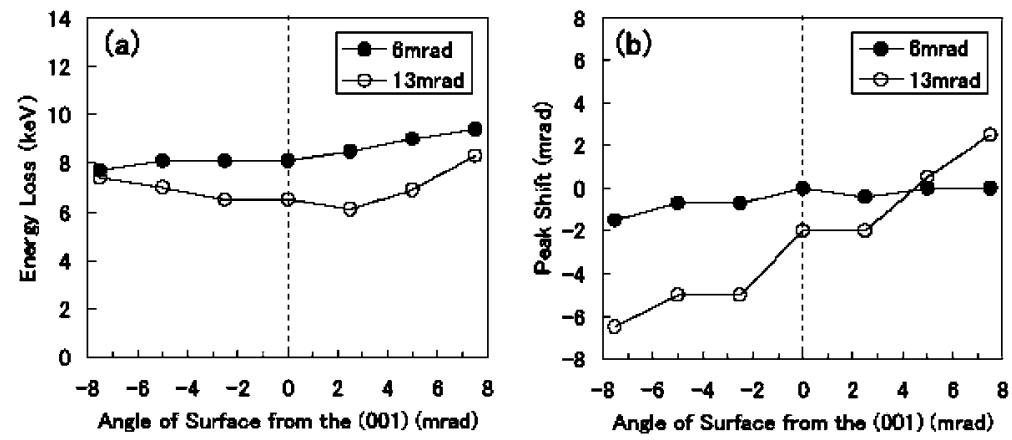

Fig. 5 Calculated results of the energy loss and peak shift of the angular distribution. (a) Mean energy loss. (b) Peak shift of the angular distribution.

で測ったエネルギースペクトルから求めたエネルギー損失と $\theta$ 分布のピークシフトを電子線照射量に対してプロットし た。結果は照射量に依存せず，ほぼ一定值をとった ${ }^{10)}$.

一方，非均一に電子線照射を行った試料の (001) 面に13 $\operatorname{mrad}$ で入射したときの $\theta$ 分布のピーク付近でのエネルギー 損失を Fig. 4 (a)に， $\theta$ 分布のピークシフトをFig. 4 (b)に 示す. 図の横軸はビーム電流から見積もった試料全面に対す る平均照射量を示す.エネルギー損失は照射量が増えると増 加する. また $\theta$ 分布のピークは散乱角の大きい方へシフトす る.

\section{4. シミュレーションおよび考察}

実験結果を説明するために，以下に示す計算機シミュレー ションを行った.

1. イオンと表面原子間の相互作用ポテンシャルとして トーマスフェルミポテンシャルのモリェール近似を用い た. イオンが表面より外で, 結晶の(001)面間隔の半分 以上表面から離れているときには, 表面連続ポテンシャ ルのもとでの軌道を計算した．これより近づいたときや 結晶内に入ったときは，衝突を扱う標的原子はイオンに 最も近接する 2 つまたは 4 つとした.

2. イオンに対する電子的阻止能として表面からの距離依 存の指数関数型を用い, 微小な進行距離ごとに偏向角を 求めた ${ }^{11)}$.

3. 表面原子の位置に関し, 熱振動振幅, 表面緩和, ラン プリングを取り入れた ${ }^{12)}$. 表面ステップとして，乱数 で位置を決めた〈100〉〈010〉2 方向に長いレッジを持
つ矩形テラスを置き重ねた．イオンにとって表面が徐々 に高くなるアップステップと表面が徐々に低くなるダウ ンステップを個別に計算した. 2 つのデータを合計した ものが一様照射のケースであるとした．

計算は $(001)$ 結晶面に対し，入射角 $\left(\theta_{\mathrm{i}}\right)$ が $6 \mathrm{mrad}$ と 13 $\operatorname{mrad}$ で行った. 一方, 入射方位角はランダム入射に対応さ せるために $\langle 100\rangle$ 軸から $100 \mathrm{mrad} に$ 固定し, それぞれの条 件で $600 \mathrm{keV}$ の $\mathrm{H}^{+}$を数万本ずつ入射してイオンの軌道とエ ネルギーを計算した. Fig. 5 にアップステップとダウンス テップをそれぞれを仮定した $\mathrm{KCl}(001)$ にイオンを入射した ときの, 散乱角分布のピーク付近でのエネルギー損失, 散乱 角分布のピークシフトを示す。横軸は入射イオンが感じる平 均表面の (001) 面に対する角度を示す. 横軸が正の側がイオ ンにとってアップステップ表面, 負の側がダウンステップ表 面を意味し, 絶対值が大きいほどステップ密度の高い表面に 相当する. アップステップ表面では，ステップ密度が増加す るにつれ, エネルギー損失, ピークシフトがともに増加して いる. AFM で観察されたものより平坦な表面を仮定したシ ミュレーションであるが，この結果が上流側を削った試料に 対する実験結果に定性的に一致するので, 以下に散乱の単純 なモデルを提示する :

入射角 $\theta_{\mathrm{i}}=13 \mathrm{mrad}$ のとき，(001) 面チャネリングの臨界 角より大きな角度で入射しているため，入射イオンは鏡面反 射を起こしにくい. イオンの多くは結晶内に潜り, 結晶原子 との近接衝突を経て散乱されてくるので，(001)結晶面では なく平均表面で散乱されているように感じる. 従ってアップ ステップのとき $\theta$ 分布のピークはステップ密度の増加と共に 

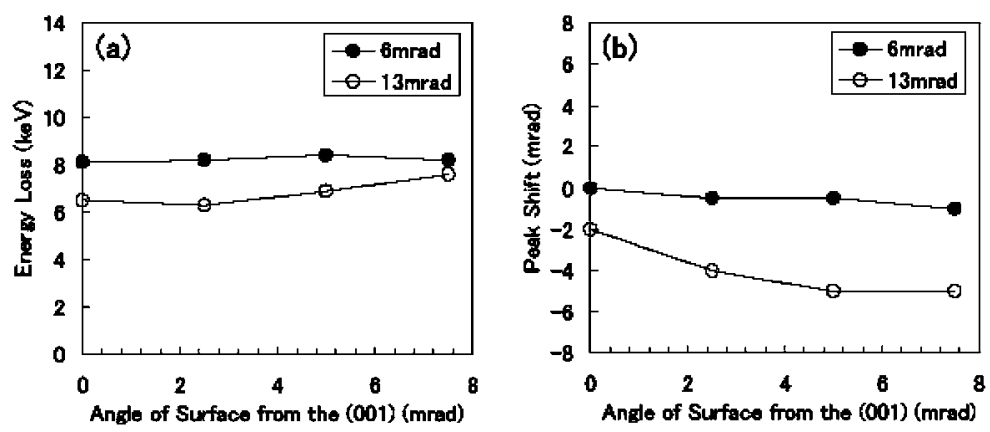

Fig. 6 Calculated results of the energy loss and peak shift of the angular distribution for surfaces irradiated uniformly. (a) Mean energy loss. (b) Peak shift of the angular distribution.

大きい方へシフトする，これらのイオンのため，エネルギー 損失もステップ密度の増加と共に大きくなる. 尚, アップス テップの試料に, $\theta_{\mathrm{i}}=6 \mathrm{mrad}$ で入射したときは, 平坦な領 域では鏡面反射が起こる．これらのイオンが十分に少なくな るほどにステップ密度を上げない限り，平均的には鏡面の角 度（12 mrad）へ散乱されることになる。

一方，アップ・ダウンステップ密度の等しい表面に対する 計算データをそれぞれ合計することにより，一様な損傷を持 った $\mathrm{KCl}(001)$ 表面での結果を求めた。 $\theta$ 分布のピーク付近 でのエネルギー損失，ピークシフトをFig. 6 に示す. ピー クシフトは起こらないかステップ密度の増加と共にわずか負 になる傾向にある．実験結果でも，これらはほとんど一定值 であったため, シミュレーションの結果は実験結果とほぼ一 致している.この結果はアップステップ表面とダウンステッ プ表面との散乱強度の違いに関係している. ダウンステップ に対しては，イオンの多くは表面に入射することなく素通り する。しかし，偶然長いテラスに入射したとき，イオンが表 面に対して出射する向きにまで散乱を受けていれば，その後， 1 原子層以上表面から離和る以前にステップに出会っても進 路を妨げられることはない，従ってアップステップとダウン ステップを均等に仮定した場合は，イオンはアップステップ 部に，より多く入射するが，検出されるものの多くはダウン ステップ部で散乱されたものである。このため，一様照射し た試料では，エネルギー損失についても，ステップ密度に対 して大きな変化はない，

\section{5. まとめ}

本研究では, 超高真空中で逐次 $5 \mathrm{keV}$ 電子線照射を行っ た試料表面での $610 \mathrm{keV} \mathrm{H}^{+}$の斜入射散乱の様子を観察し た. 電子線照射量に対して, エネルギー損失と散乱角分布の ピークを求めた．照射によって形成した試料表面の欠降密度 分布の違いで実験結果が大きく変わることが分かった。これ
らをシミュレーションと比較した。 その結果, 傾向は良く一 致し, 久陥密度分布々入射角を同時に指定することで統一的 に議論できることが分かった。この研究から，ダメージがで きた表面では, 平坦な部分での散乱とステップの部分での散 乱の強度比が効いて, 散乱角分布やエネルギー分布を変化さ せることが分かった。

\section{謝辞}

本研究を進めるに当たり, 加速器の使用に関して奈良女子 大学理学部物理科学科坂本直樹博士, 小川英巳博士, 石井邦 和博士, 狩俣順也氏に, また AFM の使用に関し神戸大学研 究基盤センターの藤居義和博士に多大な支援を受けた。記し て謝意を表す。

\section{〔文献〕}

1) P. M. Palmberg, C. J. Todd and T. N. Rhodin: J. Appl. Phys., 39 (1968) 4650.

2) S. Datz, C. D. Moak, T. S. Noggle, B. R. Appleton and H. O. Lutz: Phys. Rev., 179 (1969) 315.

3) T. S. Noggle: Nucl. Instrum. \& Methods., 102 (1972) 539.

4) H. Hoche, J. P. Toennies and R. Vollmer: Phys. Rev., B50 (1994) 679.

5) M. Szymonski, J. Kolodziej, B. Such, P. Piatkowski, P. Struski, P. Czuba and F. Krok: Prog. Surf. Sci., 67 (2001) 123.

6) D. G. Lord and M. Prutton: Thin Solid Films, 21 (1974) 341.

7) J. Nakamura, T. Kagawa and T. Osaka: Surf. Sci., 389 (1997) 109.

8) Y. Fujii: Doctor Thesis (Kyoto University, 1993).

9) Y. Susuki, K. Nishioka, M. Maehara, J. Hyoi, T. Ikeda and K. Katsura: Phys. Rev. A 69 (2004) 032710.

10）深澤優子, 光原 圭, 越智健太, 松本雄吾, 塩見祐樹, 鈴木 康文：第47回真空に関する連合講演会 講演予稿集（2006） 128.

11) K. Kimura, M. Hasegawa and M. Mannami: Phys. Rev., B 36 (1987) 7.

12) J. Vogt and H. Weiss: Surf. Sci., 491 (2001) 155. 